\title{
Analisis Kualitas Layanan dan Kepuasan Pengunjung Perpustakaan Kampus A Universitas Nahdlatul Ulama Surabaya (Unusa)
}

\author{
Denis Fidita Karya \\ Universitas Nahdlatul Ulama Surabaya \\ email:denisfk@unusa.ac.id
}

\begin{abstract}
This research conducted a survey respondents visitors to 100 library campus a Unusa. The purpose of this research is to assess the level of the quality of services and satisfaction visitors library campus a Unusa, so that it can be known how big level the quality of services and satisfaction visitors library. Research methodology it uses research quantitative so that can be described clearly of the level of the quality of services and satisfaction visitors library campus a Unusa. This research uses the importance performance analysis (ipa) used to know position strength and weakness of the indicators used. The result of research is obtainable 19 an indicator of the measurement of the quality of services library. In addition, this research results from for variables reliability and assurance having the same as it lies in quadrant two, while the rest those are variable tangible, responsiveness and empathy located at quadrant three.
\end{abstract}

Keyword(s): service quality, customer satisfaction, importance performance analysis.

\section{PENDAHULUAN}

Universitas Nahdlatul Ulama Surabaya (Unusa) didirikan oleh Yayasan Rumah Sakit Islam Surabaya (Yarsis). Embrio berdirinya berawal sejak tahun 1979, yakni berupa berdirinya Sekolah Perawat Kesehatan (SPK) Yarsis. Kemudian dalam perjalannannya berdiri pula Akademi Keperawatan Yarsis (tahun 1985), sedangkan SPK berubah menjadi Akademi Kebidanan Yarsis (tahun 1997). Tidak berhenti sampai disitu, pada tahun 2006, dua institusi tersebut (Akper-Akbid) Yarsis melakukan penyatuan institusi dan konversi menjadi Stikes Yarsis sampai dengan saat ini dengan penambahan Prodi S1 Keperawatan dan Program Profesi Ners. Stikes Yarsis yang ada di Surabaya ini dengan bekal pengalaman lebih dari 33 tahun dalam mengelola institusi pendidikan dan dorongan dari Muslimat NU, PCNU
Surabaya, PWNU, dan PBNU, maka sejak tahun 2012 mulai diajukan proses legalitas peralihan bentuk institusi ke Dikti menjadi Universitas. Sebuah lompatan besar namun terarah dari proses yang panjang tersebut, akhirnya pada tahun 2013 terbentuklah Universitas Nahdlatul Ulama Surabaya (Unusa).

Unusa merupakan perguruan tinggi yang berkomitmen tinggi mendidik mahasiswa/i dalam menghadapi tantangan global, alumni Unusa akan menjadi yang terdepan dalam bidang iptek, enterpreneurship, dan pemimpin berkarakter berlandaskan kaidah Islami. Untuk memfasilitasi 14 program studi yang saat ini telah dibuka, Unusa telah memiliki dua kampus dengan fasilitas lengkap dan modern. Ditunjang laboratorium yang lengkap untuk tiap program studi, memiliki rumah sakit sendiri (RS Islam Surabaya A. Yani dan RS Islam 
Surabaya Jemursari). Fungsi rumah sakit tersebut selain sebagai fasilitas layanan kesehatan sivitas akademika Unusa juga diperuntukan bagi kegiatan sarana praktik bagi seluruh program studi yang ada dalam menunjang pencapaian target kompetensi mahasiswa. Mempunyai laboratorium Studio Audio Visual untuk praktik micro teaching bagi Fakultas Keguruan dan Ilmu Pendidikan, serta berbagai sarana prasarana penunjang proses belajar mengajar lainnya.

Perpustakaan sebagai penyedia informasi dituntut untuk memenuhi kebutuhan pengguna seperti, dalam bidang pelayanan dan informasi, kelengkapan bahan pustaka, kenyamanan ruangan, tersedianya tempat parkir kendaraan pengunjung, serta layanan teknologi informatika yang salah satunya adalah layanan internet (bospot area). Hal tersebut berdasarkan RPJMD Nomer 15 Tahun 2009. Kotler (2009) yang menyatakan bahwa pelayanan yang berkualitas dan memuaskan perlu dilakukan terusmenerus meskipun tingkat pengaduan yang diterima rendah, karena pada umumnya sekitar 95\% konsumen yang merasa tidak puas lebih memilih untuk tidak melakukan pengaduan bahkan sebagian besar di antaranya cukup dengan menghentikan pembelian terhadap produk jasa tersebut.

Perpustakaan Unusa Kampus A telah didukung oleh teknologi informasi dalam pelaksanaan otomasi perpustakaan serta fasilitas layanan hotspot bagi penggunanya. Namun demikian, masih timbul berbagai masalah yaitu kurangnya sumber daya manusia pengguna yang menguasai teknologi informasi, kurangnya bahan pustaka, sarana dan prasarana gedung yang tidak memenuhi syarat, serta didukung dengan adanya keluhan saran dari para pengguna. Adapun saran tersebut antara lain, proses peminjaman dan pengembalian buku terkesan terburu-buru jika pengguna ramai, penataan buku yang tidak teratur, koleksi buku terlalu sedikit, belum tersedianya katalog digital, pelayanan yang kurang ramah, minimnya ruangan jika pengunjung ramai, tidak ada kartu parkir, belum ada tempat penitipan tas yang aman serta barang berharga sehingga penempatan tas masih asal-asalan dan kondisi ruangan kurang dingin ketika ramai pengunjung.

Telah dilakukan usaha peningkatan kualitas pelayanan bagi pengguna untuk mengatasi berbagai masalah yang timbul di Perpustakaan Unusa Kampus A. Peningkatan kualitas pelayanan tersebut antara lain, peningkatan kualitas sumber daya manusia pengguna melalui bimbingan dan teknologi, penambahan bahan pustaka dari dana anggaran pendapatan belanja, bantuan dari Perputakaan Nasional. Untuk sarana prasarana gedung dari dana anggaran Unusa dan bantuan. Disamping itu, peningkatan kualitas pelayanan yang telah dilakukan, dirasa masih belum sesuai dengan apa yang diharapkan oleh pengguna.

Penggunaan metode servqual dianggap cukup tepat untuk menganalisis tingkat kualitas sebuah penyedia layanan jasa karena melibatkan lima dimensi kualitas jasa. Parasuraman (1990), mengemukakan bahwa ada lima dimensi pokok kualitas pelayanan jasa yang dapat digunakan untuk mengukur tingkat kepuasan pelanggan yaitu bukti fisik (tangible), keandalan (reliability), ketanggapan (responsiveness), jaminan (assurance), dan empati (emphaty). Model servqual memang dirancang khusus untuk penyedia layanan jasa dan memandang kualitas jasa sebagai fungsi kesenjangan antara persepsi dan ekspektasi pengguna serta pada prinsipnya definisi kualitas jasa berprinsip pada 
upaya pemenuhan kebutuhan dan keinginan pengguna sekaligus ketepatan penyampaian untuk mengimbangi harapan pengguna (Tjiptono, 2011).

Sedangkan untuk membandingkan antar expectation (harapan) dengan perceived performance (kinerja perusahaan) dalam mengukur kepuasan konsumen menggunakan metode importance performance analysis (IPA) (Hidayatullah, 2006). Selain itu, juga dapat diketahui atribut yang buruk kinerjanya dan keluhan dari pengguna, dari situ dapat ditentukan langkah perbaikan secara terencana mulai dari atribut-atribut yang dianggap penting namun kinerjanya masih buruk, sehingga pengguna tetap menggunakan jasa Perpustaskaan Unusa Kampus A Surabaya. Importance performance analysis (IPA) awalnya digunakan sebagai alat untuk menyusun startegi, manajemen perusahaan. Pada hakikatnya, IPA mengombinasikan pengukuran dimensi ekspektasi dan kepentingan ke dalam dua grid, kemudian kedua dimensi tersebut diplotkan ke dalamnya. Nilai kepentingan diplotkan sebagai sumbu vertikal sedangkan nilai ekspektasi sebagai sumbu diagonal dengan menggunakan nilai ratarata yang terdapat pada dimensi kepentingan dan ekspektasi sebagai pusat pemotongan garis.

Penelitian ini untuk mengkaji tingkat kepuasan layanan pengunjung Perpustakaan Kampus A Unusa melalui metode servqual menggunakan importance performance analysis (IPA).

\section{KERANGKA TEORITIS}

Jasa

Definisi jasa menurut Kotler dan Keller (2009:25) bahwa jasa adalah sebuah aktivitas yang diasosiasikan dengan elemen intangibility (sesuatu yang abstrak), di mana di dalamnya terjadi interaksi antara pelanggan dengan penyedia jasa tetapi tidak berakibat terhadap suatu kepemilikan. Perubahan kondisi dapat saja terjadi dan produksi jasa bisa saja berkaitan dengan sebuah produk fisik. Sedangkan Rangkuti (2006) mendefinisikan jasa sebagai berikut. "Jasa merupakan pembelian suatu kineja atau tindakan tak kasat mata dari satu pihak kepada pihak lain". Pada umumnya, jasa diproduksi dan dikonsumsi secara bersamaan dimana interaksi antara pemberi jasa dan pengguna jasa memengaruhi hasil jasa tersebut.

Secara garis besar, produk dan jasa dapat ditawarkan kepada pasar dengan berbagai klasifikasi sebagai berikut (Tjiptono, 2011:21).

a. Produk berwujud murni

Penawaran yang hanya terdiri dari produk fisik, misalnya: sabun mandi, pasta gigi, atau sabun cuci tanpa adanya jasa atau pelayanan lainnya yang menyertai produk tersebut.

b. Produk berwujud disertai layanan

Penawaran yang terdiri dari suatu produk fisik yang disertai dengan satu atau beberapa layanan untuk meningkatkan daya tarik pelanggan di mana penjualannya tergantung kepada kualitas produk tersebut dan tersediannya pelayanan pelanggan, seperti: tersedianya ruang pamer, perbaikan dan pemeliharaan, operator, dan sebagainya.

c. Campuran

Tawaran ini memberikan barang dan jasa dengan proporsi yang sama, misalnya pelanggan dapat menikmati makanan dan pelayanan yang ditawarkan secara bersamaan di restoran. 
d. Jasa utama yang disertai barang dan jasa tambahan.

Tawaran yang terdiri dari jasa utama yang disertai jasa tambahan dan barang pendukung lainnya, misalnya bila pelanggan ingin naik pesawat terbang. Hal ini berarti pelanggan telah membeli jasa transportasi dan pelanggan dapat menikmati pelayanan yang ditawarkan, seperti makanan, minuman, dan majalah penerbangan selama perjalanan. Pelanggan harus naik pesawat terbang terlebih dahulu untuk menikmati produk yang ditawarkan selama perjalanan.

e. Jasa murni

Tawaran yang diberikan hanya berupa jasa, misalnya menjaga bayi, memijat, psikoterapi, dan sebagainya.

\section{Pemasaran Jasa}

Pemasaran tidak lagi dipandang sebagai proses penjualan suatu produk, namun bertujuan untuk memuaskan pelanggan dan menarik pelanggan baru dengan menjanjikan nilai yang tepat dan mempertahankan pelanggan saat ini dengan memenuhi harapannya. Menurut Kotler (2005), pemasaran adalah suatu proses sosial manajerial yang didalamnya individu dan kelompok mendapatkan apa yang mereka butuhkan dan inginkan dengan menciptakan, menawarkan, dan mempertukarkan produk yang bernilai dengan pihak lain. Menurut Yazid (2005), pemasaran jasa adalah perencanaan yang bergerak dari fokus pada transaksi menjadi hubungan jangka panjang dengan pelanggan. Sedangkan menurut Lovelock (2004), pemasaran jasa adalah bagian dari sistem jasa keseluruhan di mana perusahaan tersebut memiliki semua bentuk kontak dengan pelanggannya, mulai dari periklanan hingga penagihan yang dilakukan pada saat penyerahan jasa.

\section{Kualitas Layanan}

Menurut Tjiptono (2011) kualitas pelayanan adalah tingkat keunggulan yang diharapkan dan pengendalian atas tingkat keunggulan tersebut untuk memenuhi keinginan pelanggan. Definisi kualitas pelayanan berpusat pada upaya pemenuhan kebutuhan dan keinginan pelanggan serta penyampaian untuk mengimbangi harapan pelanggan (Simamora 2004, p180). Dari definisi-definisi tentang kualitas pelayanan tersebut dapat diambil kesimpulan bahwa kualitas pelayanan adalah segala bentuk aktivitas yang dilakukan oleh perusahaan guna memenuhi harapan konsumen.

Lovelock \& Wright (2004, 266-267) menyatakan dimensi kualitas layanan berdasarkan riset ada lima sebagai berikut.

a. Reliability: Apakah perusahaan sangat mandiri dalam menyediakan layanan setiap saat?

b. Tangibles: Seperti apakah fasilitas fisik penyedia jasa yang meliputi website, peralatan, sumber daya manusia (staff/karyawan), dan materi komunikasinya?

c. Responsiveness: Apakah staff/karyawan perusahaan sangat suka menolong dan mampu menyediakan layanan yang tepat?

d. Assurance: Apakah staff' karyawan mempunyai pengetahuan yang memadai, sopan, berkompetensi dan dapat dipercaya?

e. Emphaty: Apakah perusahaan penyedia layanan mempunyai kepedulian dan perhatian terhadap setiap individu?

Ada beberapa cara untuk mengukur kualitas layanan di antaranya servqual analysis, 
servperf analysis, dan importance performance analysis (IPA). Metode servqual adalah metode yang sering digunakan untuk mengukur kualitas pelayanan berdasarkan lima dimensi layanan dan terdiri dari 21 atribut/elemen layanan juga digunakan untuk mengetahui ktriteriakriteria kualitas yang harus ditingkatkan kualitas pelayanannya berdasarkan gap yang terjadi antara persepsi dan harapan pelanggan. Karena frekuensi penggunaannya yang tinggi, servqual dipandang memenuhi syarat validitas secara statistik (Brysland dan Curry, 2001).

\section{Importance Performance Analysis (IPA)}

Metode important performance analysis (IPA) merupakan sebuah teknik analisis pasar yang diperkenalkan pada sekitar akhir 1970 pada dunia pemasaran umum. Teknik ini mengidentifikasi kekuatan dan kelemahan produk dan layanan dengan cara membandingkan dua kriteria yang dipakai konsumen dalam mengambil keputusan: tingkat kepentingan atribut yang relatif bagi konsumen dan penilaian konsumen terhadap atribut yang mereka terima. Tidak seperti model kualitas layanan Servqual yang mengukur persepsi pelanggan secara absolut, model IPA berusaha melihat tingkat signifikansi atribut kualitas di mata konsumen dan menghubungkannya dengan beberapa kriteria kualitas yang diukur (Kitcharoen dalam Hamim, 2011).

IPA juga merupakan alat untuk mengukur Mean hanya kinerja (performance) tetapi juga pentingnya (importance) kualitas layanan menurut penilaian pelanggan berdasarkan berbagai atribut/ elemen yang sesuai. Importance merujuk pada nilai relatif terhadap atribut/ elemen layanan yang dianggap penting oleh pelanggan. Informasi tambahan inilah yang membaca analisis ini lebih cocok untuk meningkatkan kualitas layanan seperti yang diharapkan pelanggan. Tujuan IPA adalah untuk mengetahui atribut atau kombinasi atribut/ elemen mana yang lebih berpengaruh atau tidak berpengaruh dalam pembelian ulang atau pemberian rekomendasi. Selain itu, IPA juga bertujuan untuk mengetahui atribut/elemen, tetap dikelola dan dipertahankan (O'Neill \& Palmer, 2004).

Model IPA merupakan metode pengukuran kepuasan konsumen yang mendasarkan pola analisisnya pada pengaruh dua faktor, yakni harapan konsumen akan kinerja sebuah produk/jasa, dan kenyataan yang mereka terima setelah mengonsumsi produk/jasa tersebut. Konsumen akan merasa puas jika kinerja produk/jasa sama atau bahkan melebihi harapan semula. Sebaliknya, konsumen akan tidak puas jika kinerja produk/jasa tidak sesuai dengan harapannya.

Metode IPA menggunakan analisis deskriptif kualitatif-kuantitatif dalam menganalisis data penelitian untuk menjawab perumusan masalah mengenai sampai sejauh mana tingkat kepuasan konsumen terhadap kinerja suatu perusahaan. Analisis tingkat kepentingan dan kepuasan konsumen dapat menghasilkan suatu diagram kartesius yang dapat menunjukkan letak faktor-faktor atau unsur-unsur yang dianggap memengaruhi kepuasan konsumen, $\mathrm{di}$ mana dalam diagram kartesius tersebut faktorfaktor akan dijabarkan dalam empat kuadran.

Selanjutnya, tingkat unsur-unsur tersebut akan dijabarkan dan dibagi menjadi empat bagian dalam diagram kartesius matriks importance-performance sebagai berikut (Martila dan James dalam Kitcharoen, 2004). 


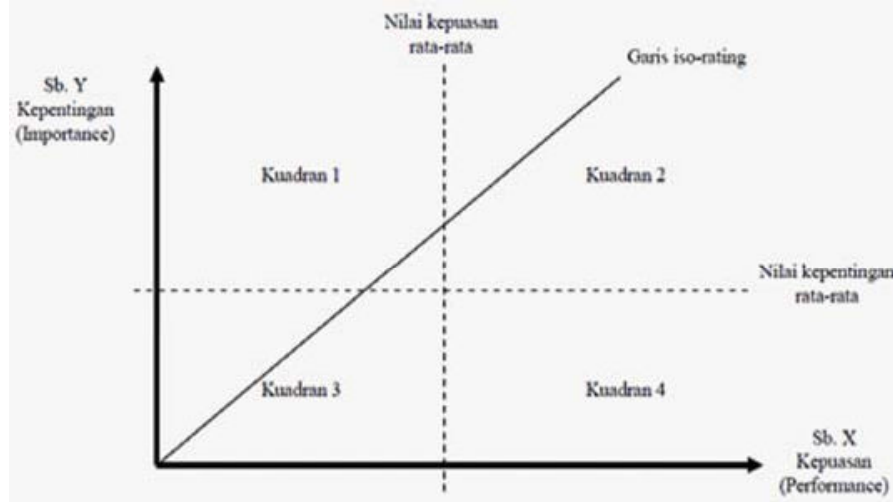

Gambar 2.2. Diagram Important Performance Analysis (Kitcharoen, 2004)

a. Kuadran 1 (Concentrate Here), merupakan wilayah yang memuat faktor-faktor yang dianggap penting oleh pengguna namun pada kenyataannya belum sesuai seperti yang diharapkan (kepuasan yang diperoleh masih sangat rendah). Konsep strategi manajerial dalam kuadran ini berupa atrributes to improve, yaitu atributatribut yang harus ditingkatkan.

b. Kuadran 2 (Keep Up the Good Work), merupakan wilayah yang memuat faktorfaktor yang dianggap penting oleh pengguna dan sudah sesuai dengan yang dirasakan sehingga tingkat kepuasannya relatif lebih tinggi. Konsep strategi manajerial dalam kuadran ini berupa maintain performance, di mana performa atribut-atribut yang masuk dalam kuadran ini harus dipertahankan.

c. Kuadran 3 (Low Priority), merupakan wilayah yang memuat faktor-faktor yang dianggap kurang penting oleh pengguna dan pada kenyataannya kinerjanya tidak terlalu memuaskan. Konsep strategi manajerial dalam kuadran ini berupa attributes to maintain, yaitu atribut bukan menjadi prioritas, melainkan dijadikan pendukung dalam sistem. d. Kuadran 4 (Possible Overkill), merupakan wilayah yang memuat faktor-faktor yang dianggap kurang penting oleh pengguna dan tetapi layanan yang disediakan dirasakan terlalu berlebihan. Konsep strategi manajerial dalam kuadran ini berupa attributes to de-emphasize, yaitu menekan kinerja atribut untuk meningkatkan efisiensi sumber daya.

\section{Kepuasan Pelanggan}

Menurut Shing (2012) kepuasan adalah suatu respons fisiologis, perasaan senang atau kecewa seseorang yang muncul setelah membandingkan antara persepsi atau kesannya terhadap kinerja (hasil) suatu produk dan harapan-harapannya sebelum dan setelah mengonsumsi produk/jasa tersebut. Tse dan Wilton dalam Lupioadi (2008) menyatakan bahwa kepuasan atau ketidakpuasan konsumen adalah respons konsumen terhadap evaluasi ketidaksesuaian yang dirasakan antara harapan sebelumnya dan kinerja aktual produk yang dirasakan setelah pemakaiannya. Selanjutnya Engel, et al. dalam Tjiptono (2011) menyatakan bahwa kepuasan konsumen merupakan evaluasi purna beli dimana alternatif yang dipilih sekurang-kurangnya sama atau melampaui harapan konsumen, sedangkan ketidakpuasan timbul apabila hasil (outcome) tidak memenuhi harapan. Dengan demikian, dapat disimpulkan bahwa definisi kepuasan konsumen adalah respons dari perilaku yang ditunjukkan oleh konsumen dengan membandingkan antara kinerja atau hasil yang dirasakan dengan harapan. Penilaian pelanggan terhadap kinerja perusahaan didapat setelah pelanggan merasakan pelayanan yang ditawarkan perusahaan. Jika harapan pelanggan lebih tinggi dari- 
pada kinerja perusahaan yang dirasakan, maka konsumen merasa tidak puas. Jika harapan konsumen sama dengan kinerja perusahaan, maka konsumen merasa puas. Jika harapan konsumen lebih rendah daripada kinerja perusahaan maka konsumen merasa sangat puas. Menurut Brierley \& MacDougall yang dikutip oleh Tjiptono (2011), tingkat kepuasan memiliki keterkaitan dengan loyalitas pelanggan. Jika pelanggan sudah berada pada tingkat kepuasan tertinggi maka pelanggan akan loyal kepada produk/jasa tersebut.

\section{Hubungan Antara Kualitas Layanan dan Ke- puasan Pelanggan}

Banyak peneliti percaya bahwa persepsi pelanggan tentang kualitas layanan merupakan evaluasi kognitif jangka panjang terhadap penyampaian layanan perusahaan. Sedangkan kepuasan pelanggan merupakan reaksi emosional jangka pendek terhadap layanan tertentu yang dialami oleh pelanggan (Lovelock \& Wright, 2004:265). Selanjutnya, Zcithaml \& Bitner (2003:92) menambahkan bahwa kualitas layanan adalah elemen utama dalam persepsi pelanggan. Untuk suatu layanan murni, kualitas layanan merupakan elemen yang dominan bagi evaluasi pelanggan. Jika layanan dikombinasikan dengan produk fisik, kualitas layanan juga merupakan hal yang sangat penting dalam memberikan kepuasan pelanggan.

Perusahaan perlu mengenali apa yang diharapkan dan diinginkan oleh pelanggan karena dua alasan. Pertama, perusahaan akan mengetahui secara lebih baik bagaimana definisi pelanggan tentang kualitas produk atau layanan. Kedua, perusahaan dapat memfasilitasi peningkatan kepuasan pelanggan melalui kuesioner (Hayes, 1997:7). Pelanggan yang puas dengan kualitas layanan akan melakukan pembelian ulang dan merekomendasikan apa yang sudah diperoleh kepada orang lain melalui mulut ke mulut (word-of-mouth recommendations). Sebaliknya, pelanggan yang tidak puas dengan kualitas layanan akan membuat yang bersangkutan tidak melakukan pembelian di masa datang atau berpindah ke produk dan layanan lain. Akibat yang lebih buruk lagi adalah jika dia menceritakan hal ini pada orang lain sehingga dapat memengaruhi dan merusak citra produk atau layanan.

Kotler \& Keller (2005:382) menambahkan bahwa pelanggan membentuk harapan akan layanan dari berbagai sumber seperti: pengalaman masa lalu, words of mouth (dari mulut ke mulut), dan iklan. Secara umum, pelanggan membandingkan layanan yang diperoleh dengan layanan yang diharapkan. Jika layanan yang diperoleh tidak sesuai dengan yang diharapkan, pelanggan akan menjadi kecewa. Jika layanan yang diperoleh sesuai atau melebihi yang diharapkan, mereka cenderung untuk menggunakan penyedia layanan itu lagi. Perusahaan-perusahaan yang berhasil adalah perusahaan yang mampu mengelola layanan sebagai penawaran yang berfungsi tidak hanya memuaskan pelanggan tetapi juga membuat mereka senang. Menyenangkan pelanggan berarti memberikan layanan yang melebihi harapan mereka.

\section{METODE PENELITIAN}

\section{Sample dan Prosedur}

Penelitian ini menyebarkan 100 kuesioner pada pengunjung (mahasiswa/mahasiswi) perpustakaan kampus A Unusa Surabaya yang dilaksanakan pada awal bulan September minggu pertama. Objek penelitian dalam hal ini 
perpustakaan memberikan jangka waktu satu minggu bagi peneliti untuk mengumpulkan data. Ternyata, dalam kurun waktu kurang dari satu minggu tersebut, terkumpul sebanyak 100 kuisioner. Maka, jumlah sampel yang digunakan dalam penelitian ini adalah 100 sampel. Penelitian ini menggunakan purposive sampling dalam mengambil sampel.

Dari total 100 responden, diketahui bahwa responden berjenis kelamin laki-laki dalam penelitian ini berjumlah 7\% (7 orang) dan responden berjenis kelamin perempuan berjumlah 93\% (93 orang). Sedangkan ditinjau dari segi usia responden pada saat penelitian berlangsung, mayoritas responden berusia 1719 tahun sebanyak 70\% (70 orang) dan usia 20-24 tahun sebanyak 30\% (30 orang). Besar responden berapa kali berkunjung ke perpustakaan dalam 1 bulan1-5 kali berjumlah 26\% (26 orang), 6-10 kali berjumlah 51\% (51 orang) dan lebih dari 10 kali berjumlah 23\% (23 orang).

\section{Variabel Penelitian dan Pengukuran}

Variabel dalam penelitian ini mengacu pada lima dimensi kualitas pelayanan sebagaimana yang dijelaskan oleh Parasuraman (dalam Fandy Tjiptono: 2011) dan berdasarkan dari peneliti terdahulu dan preeliminary interview terhadap para pengunjung. Terdapat variabel dimensi yang diukur dalam penelitian ini.

a. Tangibles (berwujud): penilaian pengunjung terhadap kondisi perpustakaan kampus A Unusa baik secara tampilan maupun fasilitas mendasar dan fasilitas pendukungnya.

b. Reliability (keandalan): penilaian pengunjung terhadap pelayanan yang dita- warkan perpustakaan kampus A Unusa terkait dengan pemenuhan janji perusahaan terhadap pengunjung dalam memberikan pelayanan, serta ketepatan waktu pelayanan.

c. Responsiveness (daya tanggap): penilaian pengunjung terhadap Kemampuan dari para staff perpustakaan kampus A Unusa dalam membantu kesulitan pengunjung, serta menindaklanjuti usulan penunjung.

d. Assurance (jaminan): penilaian pengunjung terhadap kemampuan dan pengetahuan pihak perpustakaan dalam memberikan pelayanan sehingga dapat menimbulkan kepercayaan pengunjung terhadap kinerja perpustakaan kampus A Unusa.

e. Emphaty: penilaian pengunjung bahwa layanan yang diberikan pihak perpustakaan kampus A Unusa memberikan para pengujung keistimewaan sebagai seorang pengunjung/tamu dan pelayanan yang diberikan terhadap para pengunjung telah diberikan dengan penuh kasih dan perhatian yang tulus.

\section{HASIL DAN PEMBAHASAN}

Sebelum melakukan analisis kualitas layanan dan kepuasan pengunjung perpustakaan kampus A Unusa Surabaya, maka dilakukan uji validitas dan reliabilitas pengukuran. Pengukuran validitas alat ukur (kuisioner) digunakan korelasi pearson product moment. Jika korelasi pearson product moment antara masing-masing pernyataan dengan skor total menghasilkan nilai korelasi ( $\mathrm{r}$ hitung) >0,3 maka item pernyataan dinyatakan valid.Untuk mengukur reliabilitas alat ukur (kuisioner) digunakan nilai cronbach alpha. Jika cronbach 
alpha lebih besar dari 0.6, maka kuisioner dinyatakan reliabel. Dari hasil olah data didapat bahwa semua indikator valid dan reliabel.

\section{Importance Performance Analysis (IPA)}

IPA adalah suatu rangkaian atribut layanan yang berkaitan dengan layanan khusus dievaluasi berdasarkan tingkat kepentingan masingmasing atribut menurut konsumen dan bagaimana layanan dipersepsikan kinerjanya relatif terhadap masing-masing atribut. Analisis ini digunakan untuk membandingkan antara penilaian konsumen terhadap tingkat kepentingan dari kualitas layanan (importance) dengan tingkat kinerja kualitas layanan (performance). IPA telah diterima secara umum dan dipergunakan pada berbagai bidang kajian karena kemudahan untuk diterapkan dan tampilan hasil analisis yang memudahkan usulan perbaikan kinerja. IPA mempunyai fungsi utama untuk menampilkan informasi berkaitan dengan faktor-faktor pelayanan yang menurut konsumen sangat memengaruhi kepuasan dan loyalitas mereka dan faktor-faktor pelayanan yang menurut konsumen perlu ditingkatkan karena kondisi saat ini belum memuaskan. Selain itu, juga untuk melihat faktor-faktor penting atau yang menjadi prioritas utama untuk peningkatan (misal peningkatan kualitas pelayanan). (Martinez, 2003). Dimensi kualitas layanan yang dipakai, yaitu kualitas layanan yang dikembangkan Parasuraman et al. (Purnama, 2006: 162-164). Rata-rata hasil penilaian keseluruhan konsumen kemudian digambarkan ke dalam importance-performance matrix atau sering disebut Diagram Kartesius, dengan sumbu absis $(\mathrm{X})$ adalah tingkat kinerja dan sumbu ordinat $(\mathrm{Y})$ adalah tingkat kepentingan.

\section{Perhitungan Semua Variabel (Tangibles, Reli-} ability, Responsiveness, Assurance, Emphaty)

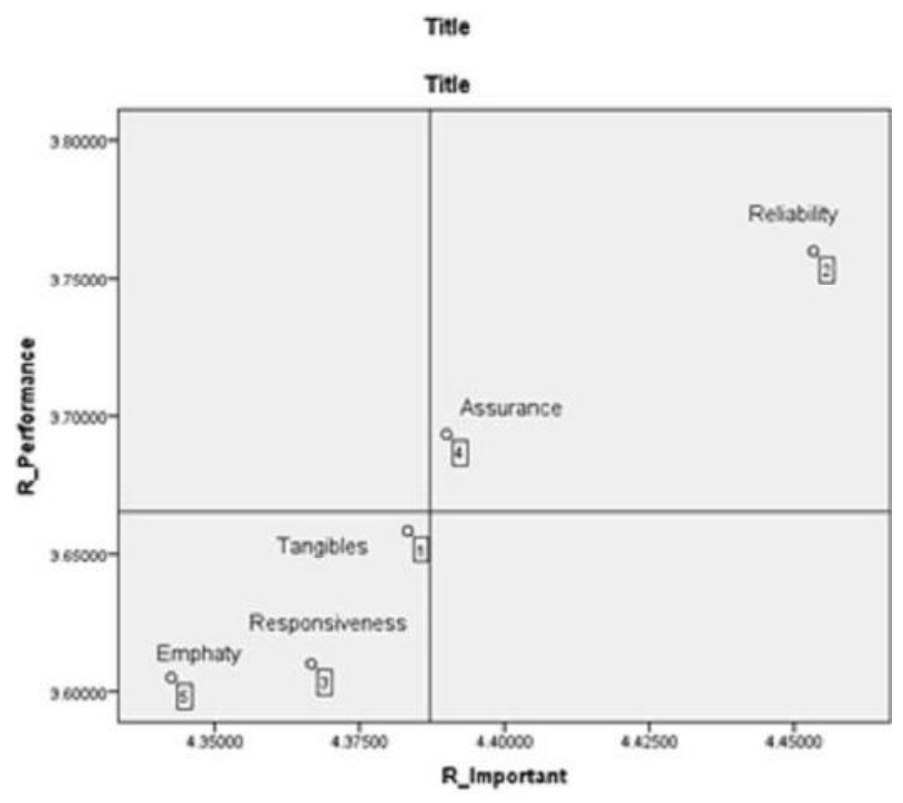

a. Kuadran 1, faktor pelayanan dari kuadran ini tidak ada.

b. Kuadran 2, faktor pelayanan dari kuadran ini adalah variabel reliability dan assurance. Artinya dari variabel assurance dan reliability tersebut perlu dipertahankan, karena variabel assurance dan reliability pada kuadran ini dianggap sangat penting dan sangat memuaskan.

c. Kuadran 3, faktor pelayanan dari kuadran ini adalah variabel tangibles, responsiveness, dan emphaty. Artinya, dari ketiga variabel tersebut kurang penting dan kurang memuaskan pengaruhnya bagi pengunjung perpustakaan. Untuk itu, pihak manajemen sebaiknya memperhatikan faktor yang ada dalam ketiga variabel ini.

d. Kuadran 4, faktor pelayanan dalam kuadran ini tidak ada. 


\section{Perhitungan Berdasarkan Variabel Tangibles}

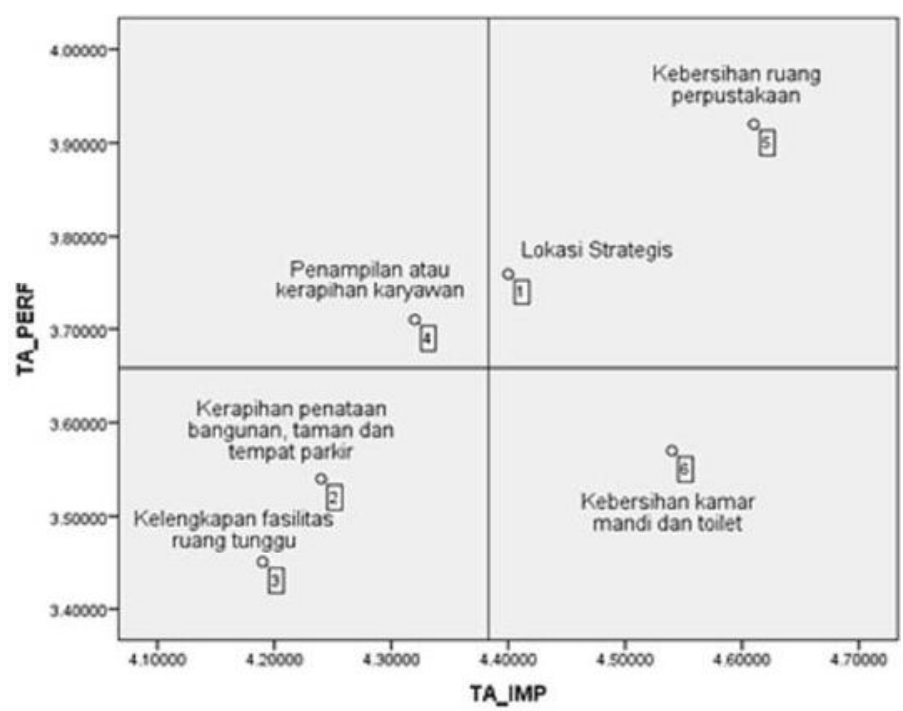

a. Kuadran 1, faktor pelayanan dari kuadran ini adalah penampilan atau kerapian karyawan. Artinya penampilan atau kerapian karyawan perlu diprioritaskan untuk ditingkatkan, karena harapan penampilan atau kerapian karyawan tinggi sedangkan realisasi penampilan atau kerapian karyawan tidak sesuai dengan harapan yaitu masih rendah. Faktor di kuadran ini dianggap sangat penting, namun pihak manajemen belum melaksanakan sesuai keinginan pengunjung perpustakaan sehingga tidak memuaskan.

b. Kuadran 2, faktor pelayanan dari kuadran ini adalah lokasi yang strategis. Artinya faktor perpustakaan yang strategis perlu dipertahankan, karena faktor pada kuadran ini dianggap sangat penting dan sangat memuaskan. Hal ini memang posisi perpustakaan berada di kampus yang pertama berdiri serta memiliki banyak mahasiswa.

c. Kuadran 3, faktor pelayanan dari kuadran ini adalah kerapian penataan bangunan taman dan tempat parkir serta kelengkapan fasilitas ruang tunggu. Artinya dari kerapian penataan bangunan taman dan tempat parkir serta kelengkapan fasilitas ruang tunggu tersebut kurang penting dan kurang memuaskan pengaruhnya bagi pengunjung perpustakaan. Untuk itu pihak manajemen sebaiknya memperhatikan faktor yang ada dalam kuadran ini.

d. Kuadran 4, faktor pelayanan dalam kuadran ini adalah kebersihan kamar mandi dan toilet. Artinya dari faktor tersebut kurang penting memengaruhi pengunjung perpustakaan, akan tetapi dalam pelaksanaannya berlebihan, dianggap kurang penting tetapi sangat memuaskan.

\section{Perhitungan Berdasarkan Variabel Reliability}

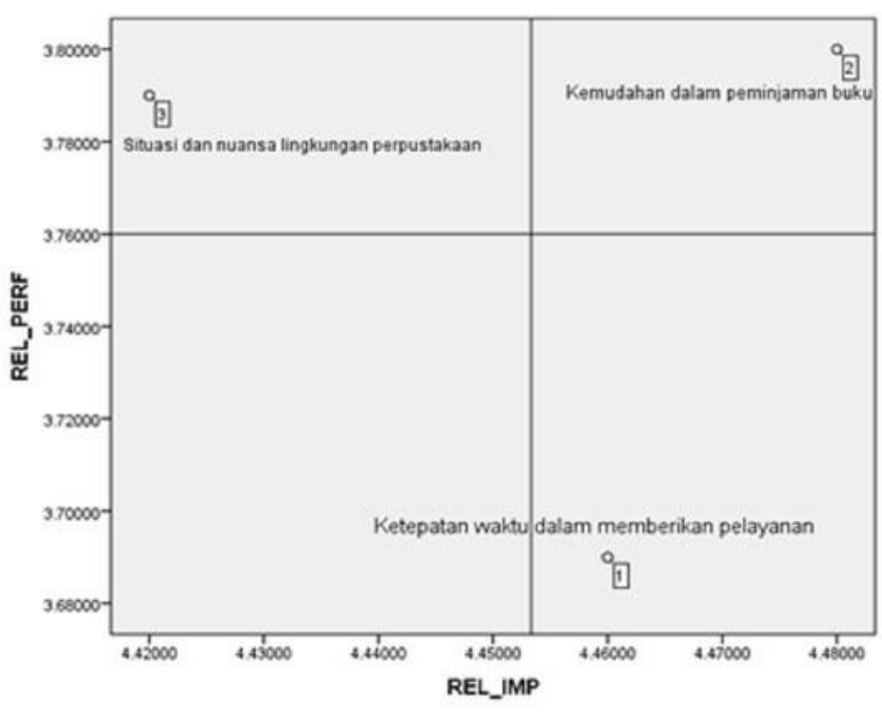

a. Kuadran 1, faktor pelayanan dari kuadran ini adalah situasi dan nuansa lingkungan perpustakaan. Artinya situasi dan nuansa lingkungan perpustakaan perlu diprioritaskan untuk ditingkatkan, karena harapan situasi dan nuansa lingkungan perpustakaan tinggi sedangkan realisasi situasi dan nuansa lingkungan perpustakaan tidak sesuai dengan harapan yaitu masih rendah. Faktor di kuadran ini dianggap sangat penting, namun pihak manajemen belum melaksanakan sesuai keinginan pengunjung perpustakaan sehingga tidak memuaskan. 
b. Kuadran 2, faktor pelayanan dari kuadran ini adalah kemudahan dalam peminjaman buku. Artinya, faktor kemudahan dalam peminjaman buku perlu dipertahankan, karena faktor pada kuadran ini dianggap sangat penting dan sangat memuaskan. $\mathrm{Hal}$ ini memang adanya jaminan terkait dengan kemudahan peminjaman buku.

c. Kuadran 3, faktor pelayanan dari kuadran ini tidak ada.

d. Kuadran 4, faktor pelayanan dalam kuadran ini adalah ketepatan waktu dalam memberikan pelayanan. Artinya, dari faktor tersebut kurang penting memengaruhi pengunjung perpustakaan, akan tetapi dalam pelaksanaannya berlebihan, dianggap kurang penting tetapi sangat memuaskan.

\section{Perhitungan berdasarkan variabel Respon- siveness}

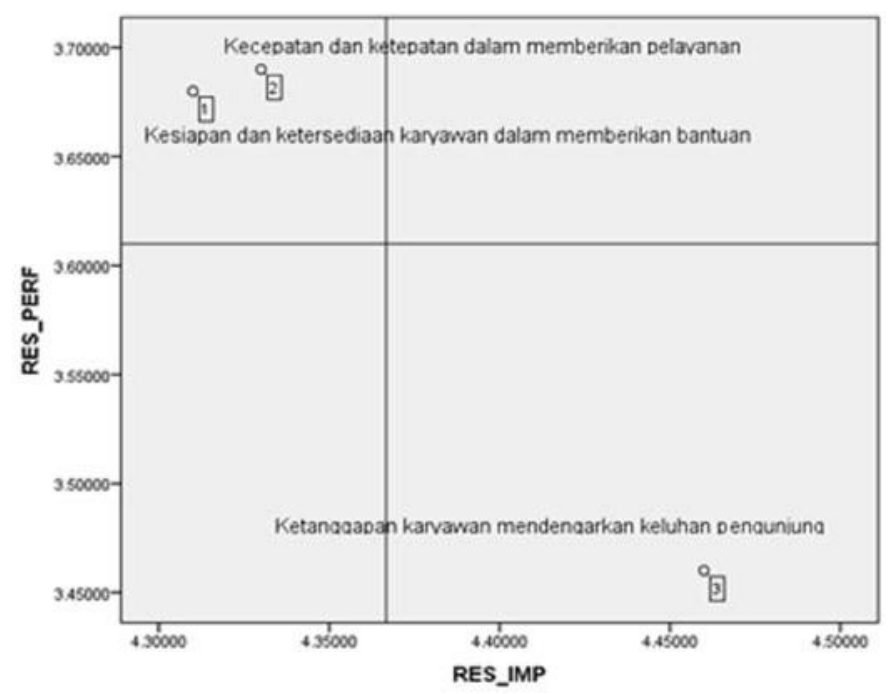

a. Kuadran 1, faktor pelayanan dari kuadran ini adalah kecepatan dan ketepatan dalam memberikan pelayanan serta kesiapan dan ketersediaan karyawan dalam memberikan bantuan. Artinya, kecepatan dan ketepatan dalam memberikan pelayanan serta kesiapan dan ketersediaan karyawan dalam mem- berikan bantuan perlu diprioritaskan untuk ditingkatkan, karena harapan kecepatan dan ketepatan dalam memberikan pelayanan serta kesiapan dan ketersediaan karyawan dalam memberikan bantuan tinggi sedangkan realisasi tidak sesuai dengan harapan yaitu masih rendah. Faktor di kuadran ini dianggap sangat penting, namun pihak manajemen belum melaksanakan sesuai keinginan pengunjung perpustakaan sehingga tidak memuaskan.

b. Kuadran 2, faktor pelayanan dari kuadran ini tidak ada.

c. Kuadran 3, faktor pelayanan dari kuadran ini tidak ada.

d. Kuadran 4, faktor pelayanan dalam kuadran ini adalah ketanggapan karyawan mendengarkan keluhan pengunjung perpustakaan. Artinya, dari faktor tersebut kurang penting memengaruhi pengunjung perpustakaan, akan tetapi dalam pelaksanaannya berlebihan, dianggap kurang penting tetapi sangat memuaskan.

\section{Perhitungan berdasarkan variabel Assurance}

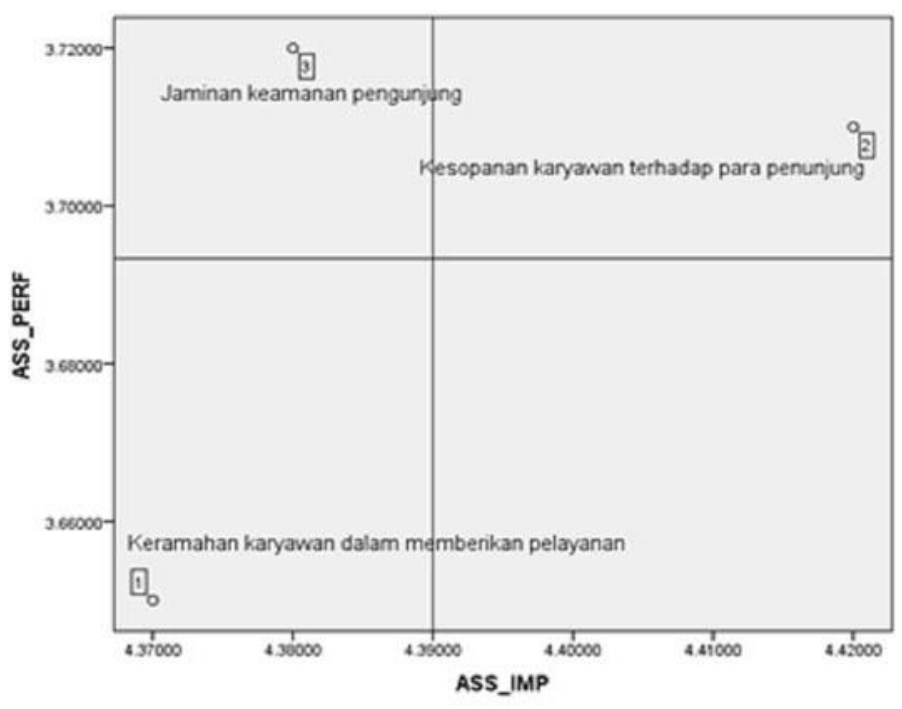

a. Kuadran 1, faktor pelayanan dari kuadran ini adalah jaminan keamanan pengunjung 
perpustakaan. Artinya, jaminan keamanan pengunjung perpustakaan perlu diprioritaskan untuk ditingkatkan, karena harapan jaminan keamanan pengunjung perpustakaan tinggi sedangkan realisasi masih rendah. Faktor di kuadran ini dianggap sangat penting, namun pihak manajemen belum melaksanakan sesuai keinginan pengunjung perpustakaan sehingga tidak memuaskan.

b. Kuadran 2, faktor pelayanan dari kuadran ini kesopanan karyawan terhadap pengunjung. Artinya, faktor kesopanan karyawan terhadap pengunjung perlu dipertahankan, karena faktor pada kuadran ini dianggap sangat penting dan sangat memuaskan.

c. Kuadran 3, faktor pelayanan dari kuadran ini keramahan karyawan dalam memberikan pelayanan. Artinya, dari keramahan karyawan dalam memberikan pelayanan tersebut kurang penting dan kurang memuaskan pengaruhnya bagi pengunjung perpustakaan. Untuk itu, pihak manajemen sebaiknya memperhatikan faktor yang ada dalam kuadran ini.

d. Kuadran 4, faktor pelayanan dalam kuadran ini tidak ada.

\section{Perhitungan berdasarkan variabel Assurance}

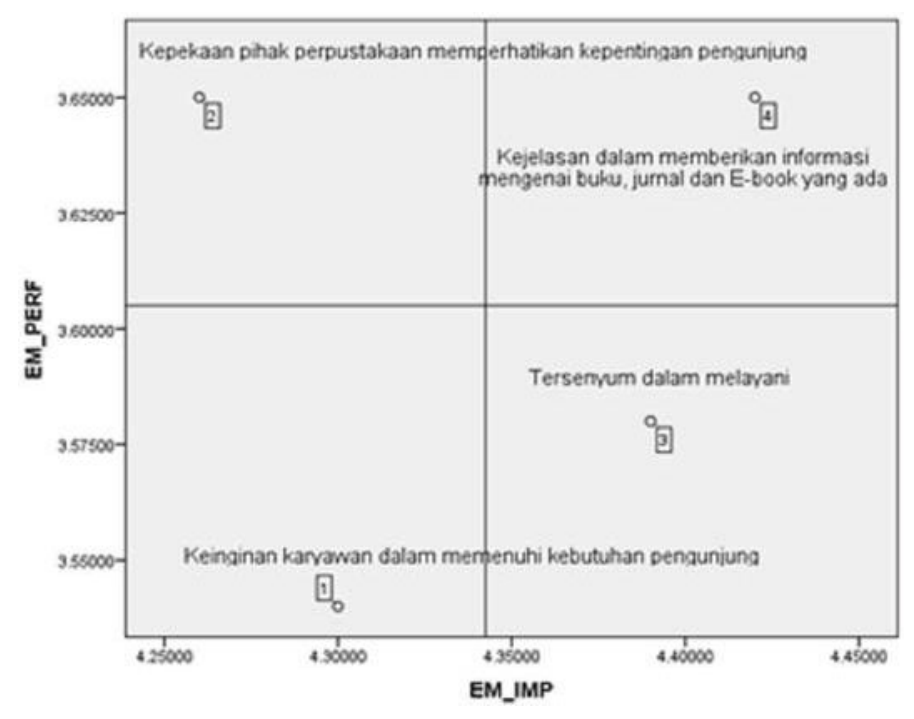

a. Kuadran 1, faktor pelayanan dari kuadran ini adalah kepekaan pihak perpustakaan dalam memperhatikan kepentingan pengunjung. Artinya, kepekaan pihak perpustakaan dalam memperhatikan kepentingan pengunjung perlu diprioritaskan untuk ditingkatkan, karena harapan kepekaan pihak perpustakaan dalam memperhatikan kepentingan pengunjung tinggi sedangkan realisasi tidak sesuai dengan harapan yaitu masih rendah. Faktor di kuadran ini dianggap sangat penting, namun pihak manajemen belum melaksanakan sesuai keinginan pengunjung perpustakaan sehingga tidak memuaskan.

b. Kuadran 2, faktor pelayanan dari kuadran ini adalah kejelasan dalam memberikan informasi mengenai buku, jurnal, dan ebook. Artinya, faktor kejelasan dalam memberikan informasi mengenai buku, jurnal dan e-book perlu dipertahankan, karena faktor pada kuadran ini dianggap sangat penting dan sangat memuaskan. Hal ini memang mahasiswa cukup butuh banyak informasi terkait buku, jurnal, dan e-book yang ada di perpustakaan.

c. Kuadran 3, faktor pelayanan dari kuadran ini adalah keinginan karyawan dalam memenuhi kebutuhan pengunjung. Artinya, dari keinginan karyawan dalam memenuhi kebutuhan pengunjung tersebut kurang penting dan kurang memuaskan pengaruhnya bagi pengunjung perpustakaan. Untuk itu pihak manajemen sebaiknya memperhatikan faktor yang ada dalam kuadran ini.

d. Kuadran 4, faktor pelayanan dalam kuadran ini adalah tersenyum dalam melayani. Artinya, dari faktor tersebut kurang penting memengaruhi pengunjung perpustakaan, 
akan tetapi dalam pelaksanaannya berlebihan, dianggap kurang penting tetapi sangat memuaskan.

\section{PEMBAHASAN}

Dengan analisis Importance Performance Analysis (IPA) secara keseluruhan maka dapat diketahui masih terdapat beberapa hal yang harus dipertahankan kedepannya yaitu lokasi perpustakaan yang strategis, bertempat di tengah kota, serta banyaknya mahasiswa yang berada di lokasi kampus. Selain itu, kebersihan ruang perpustakaan menjadi faktor keunggulan karena pengunjung merasa ruang perpustakaan cukup bersih. Selain itu, faktor lain yang menjadi keunggulan yaitu kemudahan dalam peminjaman buku, di perpustakaan ini sangat mudah sekali prosedur dalam melakukan peminjaman buku yang didukung teknologi sistem informasi dalam hal peminjaman buku. Selain itu, kinerja yang patut dipertahankan yaitu kesopanan karyawan terhadap pengunjung, kemudian adanya kejelasan dalam memberikan informasi terkait koleksi buku, jurnal, maupun e-book yang ada dalam perpustakaan.

Adapun kelemahan atau kekurangan dari kinerja di Perpustakaan Kampus A Unusa Surabaya ini untuk dibenahi kedepannya. Pertama, mengenai penampilan dan kerapian karyawan, dimana hal ini menjadi faktor yang perlu dicermati oleh pihak manajemen dan harus segera melakukan tindakan, karena dengan karyawan yang rapi serta berpenampilan yang baik akan membuat pengunjung merasa nyaman ketika berada di perpustakaan. Kedua, mengenai situasi dan nuansa lingkungan perpustakaan, faktor ini dirasa kurang oleh pengunjung perpustakaan karena situasi dan lingkungan perpustakaan yang dekat dengan areal kantin dari kampus sendiri. Hal ini mem- buat situasi dan nuansa yang tidak kondusif ketika pengunjung yang ingin mendapatkan situasi yang tenang serta nuansa yang nyaman ketika berada di perpustakaan. Ketiga, mengenai kecepatan dan ketepatan dalam memberikan pelayanan. Faktor ini dirasa kurang oleh pengunjung perpustakaan, hal ini karena ketika pengunjung perpustakaan penuh dan melakukan proses peminjaman atau pengembalian petugas yang jaga hanya sedikit sehingga terjadi antrian yang cukup panjang. Keempat, mengenai kesiapan dan ketersediaan karyawan dalam memberikan bantuan bagi pengunjung perpustakaan. Kelima, mengenai jaminan keamanan pengunjung perpustakaan. Hal ini paling utama yang harus dicermati oleh pihak manajemen perpustakaan terkait keamanan bagi pengunjung terutama pada loker pada penitipan tas yang cukup rawan untuk hilang apabila ada mahasiswa yang lalai ketika menyimpan benda berharga dalam tas tersebut, dikarenakan posisi loker tersebut berada di luar tanpa ada penjagaan dari petugas perpustakaan. Keenam, mengenai kepekaan pihak perpustakaan memperhatikan kepentingan pengunjung.

\section{Implikasi Penelitian}

Hasil penelitian mengenai penilaian kualitas layanan pengguna jasa Perpustakaan Kampus A Unusa Surabaya, diketahui bahwa menurut responden ada 19 atribut yang memengaruhi penilaian mereka terhadap kinerja pelayanan jasa Perpustakaan kampus A Unusa Surabaya. Didapat kekuatan dan kelemahan dari perpustakaan berdasarkan penilaian pengunjung. Kekuatan perpustakaan terletak pada lokasi yang strategis, kebersihan ruang perpustakaan, kemudahan dalam peminjaman 
buku, kesopanan karyawan terhadap pengunjung dan kejelasan dalam memberikan informasi terkait koleksi buku, jurnal, maupun ebook. Adapun kelemahan yang dimiliki Perpustakaan Unusa Kampus A Surabaya, yaitu masalah penampilan dan kerapian karyawan, situasi dan nuansa lingkungan perpustakaan, kecepatan dan ketepatan dalam memberikan pelayanan, kesiapan dan ketersediaan karyawan dalam memberikan bantuan bagi pengunjung perpustakaan, jaminan keamanan pengunjung, dan kepekaan pihak perpustakaan memperhatikan kepentingan pengunjung.

Terdapat beberapa keterbatasan dalam penelitian ini, maka dari itu terdapat beberapa saran untuk riset berikutnya. Mayoritas responden pada penelitian ini merupakan individu dengan usia rata-rata 17-20 tahun dan mayoritas adalah wanita. Oleh karena itu, akan lebih baik jika penelitian selanjutnya dapat melibatkan responden dengan usia lebih di atas 20 tahun dan/atau dengan gender yang seimbang antara pria dan wanita. Peneliti juga menyadari bahwa jumlah sampel kurang memenuhi ketentuan sehingga harus dilakukan penggantian teknik analisis dalam mengolah data. Oleh karena itu, hendaknya penelitian selanjutnya dapat menggunakan sampel yang sesuai dan memenuhi ketentuan.

\section{DAFTAR PUSTAKA}

Amstrong \& Kotler. 2004. Dasar-Dasar Pemasaran (Terjemahan), Jilid Dua. Jakarta: PT INDEKS.

Bitner, M.J. dan Zeithaml, V.A. 2003. Service Marketing (3rd ed.). New Delhi: Tata McGraw Hill.
Brysland, Alexandria dan Curry, Adrienne. 2001. "Service Improvements in Public Services using Servqual”. Managing Service Quality, Vol. 11 (6), hal. 389-401. Kotler \& Keller. 2009. Marketing Management, Penerjemah Bob Sabran, Edisi Ketiga Belas. Jakarta: Erlangga.

Kotler, Philip. 2005. Manajemen Pemasaran, Jilid 2, Edisi Kesebelas. Jakarta: PT INDEKS.

Kitcharoen, Krisana. 2004. "The ImportancePerformance Analysis of Service Quality in Administrative Departements of Private Universities in Thailand". The Journal of Management, Vol. 24 No. 3 2004: 20-46.

Lovelock and Wirtz. 2004. Service Marketing, Fifth Edition. Pearson Prentice Hall. Lupiyoadi, Rambat. 2008. Manajemen Pemasaran Jasa, Edisi 2. Depok: Salemba Empat.

O'Neill, Martin and Palmer, Adrian. 2004. "The Effects of Experience on the Temporal Stability of Service Quality Dimentions", ANZMAC 2002 Conference Proceedings. Pp. 2813-2817.

Rangkuti, Freddy. 2006. Measuring Customer satisfaction. Jakarta: PT Gramedia Pustaka Utama.

Simamora, Bilson. 2004. Panduan Riset Perilaku Konsumen. Jakarta: PT Gramedia Pustaka Utama.

Tjiptono, Fandy. 2011. Service, Quality, \& Satisfaction. Yogyakarta: Andi.

Yazid. 2005. Pemasaran Jasa dan Konsep Implementasi. Yogyakarta: Ekonisia. 